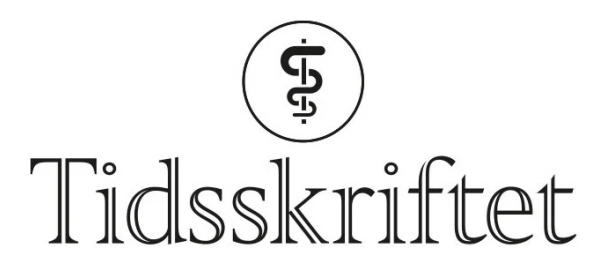

DEN NORSKE LEGEFORENING

\title{
For deg som synes sykemelding er vanskelig
}

ANMELDELSER

STEINAR KROKSTAD

Professor i sosialmedisin, HUNT forskningssenter, Institutt for samfunnsmedisin og sykepleie, NTNU

Hans Magnus Solli

Personsentrert trygdemedisin i etiske perspektiver

Sykdom, funksjonsevne, ressurser og objektive erklæringer. 185 s, tab, ill. Oslo: Norsk trygdemedisinsk forening, 2020. Gratis tilgjengelig på nett

ISBN 978-82-996401-2-1

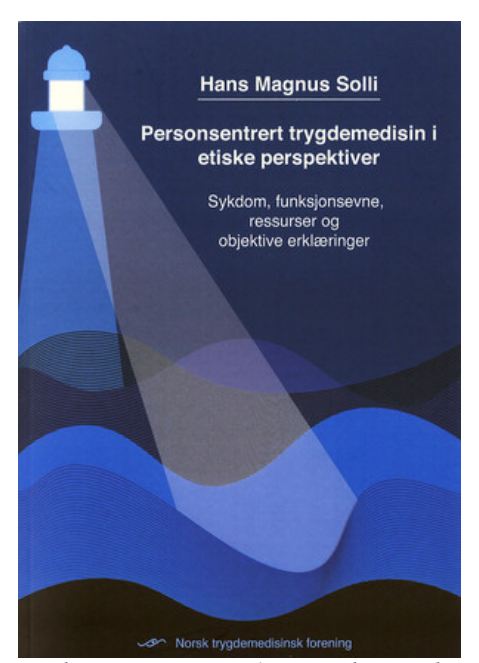

Lederen av Norsk trygdemedisinsk forening sier i sitt forord at denne boken er en milepæl i foreningens historie. Helt siden Hans Magnus Solli startet på arbeidet med sin doktorgradsavhandling, som ble publisert i 2007, har han ryddet i begreper, knyttet trygdemedisinsk arbeid til den vitenskapelige tradisjon og etablert et moderne praktisk og etisk grunnlag for leger som praktiserer trygdemedisin. Dette inkluderer fastleger, spesialister og rådgivende leger i NAV. Men innholdet er av interesse for flere-politikere, samfunnsvitere, andre NAV-ansatte og jurister. 
Boken er inndelt i åtte kapitler. Det første beskriver handlingsrommet mellom fag, juss og etikk. Videre omtales blant annet funksjonsevne og ressurser i et bio-psyko-sosialt perspektiv, forskjellen på biomedisinske og verdiladede relasjonelle sykdomsbegreper, teori om helse, sykdom og ressurser, medisinske vilkår for sykepenger og det etiske grunnlaget for trygdemedisinen.

«Fibromyalgikjennelsen» fra Trygderetten i 1994 omtales som en milepæl i norsk trygdemedisinsk historie. Kjennelsen førte til at sykdom uten objektive funn ble anerkjent som grunnlag for medisinske trygdeytelser. Helt nødvendig, ettersom sykdomspanoramaet i dag ikke lenger er dominert av fysiske skader blant fabrikkarbeidere, men stressrelaterte psykiske symptomer, utbredte smerter og utmattelse drevet av en nyliberalistisk ideologi.

Solli peker videre på at det etiske grunnlaget for trygdemedisinen bygger på respekten for menneskeverdet og de tilhørende menneskerettighetene. Menneskeverdet er konstant, uten gradering, betingelsesløst, ukrenkelig og umistelig. Han henviser til fem gode etiske prinsipper for leger som rettesnor i det trygdemedisinske arbeidet: menneskerettighetene, ikke-skade-prinsippet, velgjørenhet, autonomi og sosial rettferdighet.

Deretter blir boken mer praktisk anlagt og hjelper oss å skille mellom objektivitet og subjektivitet i erklæringsutforming og i sakkyndighetsrollen. Temaer som også blir omtalt, er hvordan man skal ivareta balansen mellom taushetsplikt og opplysningsplikt, og kravet om varsomhet og samarbeid med pasienten i utforming av erklæringer.

Avslutningsvis deler Solli tanker om menneskehetens framtid på kloden, i antropocen, og behovet for å finne en bærekraftig balanse mellom samfunn, økonomi, politikk, kultur og naturen. Verdiene velferdsstaten bygger på, er også sentrale tema for en slik strategi.

Boken anbefales varmt for alle som synes trygdemedisin i praksis er utfordrende.

Publisert: 28. februar 2022. Tidsskr Nor Legeforen. DOI: 10.4045/tidsskr.21.0857

(C) Tidsskrift for Den norske legeforening 2023. Lastet ned fra tidsskriftet.no 26. april 2023. 